\title{
Upaya Peningkatan Ketrampilan Menyusun Laporan Keuangan Bagi Pengurus Koperasi Batik Tegalan Cempaka Mulya
}

\author{
Hetika $^{1}$, Yeni Priatna Sari ${ }^{2}$, Ririh Sri Harjanti ${ }^{3}$ \\ ${ }^{1,2,3}$ Program Studi Akuntansi, Politeknik Harapan Bersama \\ e-mail: 'hetika.maksi@gmail.com, ${ }^{2}$ yeni.priatna@gmail.com, ${ }^{3}$ ririh.sriharjanti77@gmail.com
}

\begin{abstract}
Abstrak
Koperasi adalah organisasi bisnis yang dioperasikan untuk kepentingan bersama dengan tujuan untuk kesejahteraan anggota. Koperasi Batik Cempaka Mulya merupakan koperasi yang didirikan oleh masyarakat Kampung Batik Tegalan yang bertujuan untuk meningkatkan kesejahteraan anggota. Harapan dari koperasi batik cempaka mulya adalah tersedianya seluruh keperluan membatik di koperasi batik sehingga dapat memfasilitasi para pengrajin batik. Koperasi batik membutuhkan dukungan dari pihak lain khusunya terkait dengan pembiayaan. Dukungan pembiayaan yang dibutuhkan oleh Kelompok Usaha Bersama Batik Tegalan telah direspon oleh pihak Pembiayaan BNI Kota Tegal, namun untuk mendapatkan pembiayaan dari BNI koperasi batik harus menyusun laporan keuangan sebagai bentuk pertanggung jawaban keuangan, sehingga pengurus koperasi batik membutuhkan dukungan dari pihak akademisi untuk mendapatkan pelatihan penyusunan laporan keuangan koperasi. Metode yang digunakan dalam pengabdian masyarakat ini adalah pelatihan dan pendampingan penyusunan laporan keuangan koperasi batik Cempaka Mulya. Metode pengumpulan data kegiatan pengabdian ini adalah melalui observasi dan wawancara dengan pengurus koperasi serta dinas terkait. Secara garis besar kegiatan pelatihan ini dapat dinyatakan berhasil dilihat dari antusiasme para pengurus koperasi selama proses pelatihan dan pendampingan penyusunan laporan keuangan. Selain itu kegiatan pelatihan ini dapat berkontribusi dalam peningkatan pengetahuan dan ketrampilan pengurus koperasi serta membantu Disperindag Kota Tegal dalam program pembinaan Kelompok Usaha Bersama Batik.
\end{abstract}

Kata kunci-pelatihan, laporan keuangan, koperasi

\section{PENDAHULUAN}

Koperasi adalah organisasi bisnis yang dimiliki dan dioperasikan oleh orang seorang demi kepentingan bersama. Koperasi merupakan kegiatan ekonomi yang berdasarkan atas asas kekeluargaan. Di Indonesia koperasi merupakan salah satu soko guru perekonomian selain sektor pemerintah dan swasta (Sinarwati, Ni Kadek dkk, 2014) ${ }^{[1]}$. Hal ini menunjukkan pentingnya koperasi di Indonesia. Terdapat beberapa jenis koperasi yang ada di Indonesia dan tersebar di seluruh wilayah Indonesia salah satunya di Kota Tegal.

Kalinyamat merupakan salah satu kelurahan yang berada di kecamatan margadana Kota Tegal, yang terkenal sebagai kampung batik. Batik merupakan salah satu warisan budaya yang masih eksis dan dilestarikan dan merupakan salah satu sumber penghasilan masyarakat Kelurahan kalinyamat kota Tegal. Dilihat dari perkembangannya, saat ini batik sudah menjadi sebuah life style dalam dunaia fashion. Hal ini pun didukung oleh pemerintah kota Tegal salah satunya dengan mewajibkan karyawan untuk memakai batik tegalan sebagai seragam. Batik tegalan saat ini telah mengalami perkembangan dan kemajuan baik dari segi produksi, kualitas maupun pemasaran. 
Koperasi Batik Tegalan Cempaka Mulya merupakan salah satu koperasi yang beranggotakan pengrajin batik di kelurahan kalinyamat. Koperasi Cempaka Mulya didirikan dengan harapan dapat membantu penyediaan bahan baku untuk produksi batik tegalan, penyediaan peralatan dan membantu menjual dan memasarkan batik. Demikian besar harapan para pengrajin batik di kelurahan kalinyamat akan perkembangan koperasi Cempaka Mulya, karena perkembangan koperasi juga berarti perkembangan kehidupan masyarakat kampong batik. Sebagai lembaga yang menjadi harapan bagi masyarakat pengrajin batik, sehingga pengurus koperasi hendaknya dapat mengelola dan mempertanggungjawabkan dana secara akuntabel melalui pelaporan keuangan dalam kegiatan Rapat Anggota Tahunan (RAT). Namun keunyataannya koperasi Cempaka Mulya belum melaksanakan RAT salah satunya disebabkan karena pengurus koperasi Cempaka Mulya belum mampu dalam menyusun laporan keuangan koperasi.

Laporan keuangan adalah sarana utama yang digunakan oleh perusahaan untuk mengkomunikasikan informasi keuangan kepada pihak luar. Laporan keuangan merupakan sejarah perusahaan yang diukur dengan satuan uang (Kieso dan Weygant, 2005) [2]. Laporan keuangan merupakan salah satu laporan yang harus disusun oleh pengurus koperasi sebagai bentuk peratanggung jawaban terhadap pengelolaan dana kepada anggota selaku pemilik koperasi. Saelain itu, dengan menyusun laporan keuangan koperasi memiliki dokumen penunjang untuk mengajukan permohonan pinjaman dana di bank dan masih banyak lagi kegunaan disusunnya laporan keuangan.

Berdasarkan diskusi dengan pengurus Koperasi batik Cempaka Mulya permasalahan yang dihadapi oleh pengurus koperasi adalah pengurus koperasi belum mampu menyusun laporan keuangan, sehingga kegiatan ini bertujuan untuk memberikan pelatihan penyusunan laporan keuangan kepada pengurus koperasi. Dengan adanya kegiatan ini diharapkan pengurus koperasi dapat menyusun laporan keuangan koperasi.

Kegiatan pengabdian masyarakat ini diharapkan dapat bermanfaat dengan memberikan kemampuan kepada pengurus koperasi untuk menyusun laporan keuangan sehingga pengurus mampu mewujudkan tata kelola koperasi yang transparan dan dapat dipertanggungjawabkan. Apabila laporan keuangan dapat disusun maka kepercayaan stake holder dapat meningkat, sehingga menambah peluang untuk meningkatkan modal koperasi.

\subsection{Khalayak Sasaran}

\section{METODE}

Khalayak sasaran pengabdian masyarakat adalah pengurus koperasi Batik Tegalan Cempaka Mulya. Koperasi Batik Tegalan Cempaka Mulya merupakan koperasi yang didirikan dengan tujuan untuk kesejahteraan anggota koperasi. Dengan adanya koperasi diharapkan dapat memajukan industri batik Tegalan, sehingga dapat memajukan perekonomian masyarakat di Kampung Batik.

\subsection{Metode Kegiatan}

Metode pelaksanaan kegiatan dalam kegiatan pengabdian masyarakat ini adalah metode ceramah, tutorial dan diskusi serta praktek, dimana dalam kegiatan ini peserta pengabdian masyarakat dierikan tutorial tentang penyusunan laporan keuangan koperasi dan mempraktekkan apa yang telah disampaikan.

\subsection{Tahap Kegiatan PKM}

\subsubsection{Tahap Persiapan}

Dalam tahap persiapan beberapa hal yang dilakukan adalah:

a. Persiapan adminidtrasi yang diperlukan misalnya perijinan dan undangan peserta pengabdian masyarakat

b. Koordinasi dengan pengurus Koperasi Batik Cempaka Mulya yang dimediasi oleh pihak Disperindag Koperasi Kota Tegal.

c. Persiapan materi pelatihan 
d. Persiapan jadwal dan pelaksanaan pelatihan

\subsubsection{Pemetaan}

Pemetaan dilakukan pada saat menganalisis situasi dengan memetakan permasalahan apa yang dihadapi dan solusi apa yang dibutuhkan. Dari hasil pemetaan yang dibutuhkan oleh pengurus koperasi adalah pelatihan penyusunan laporan keuangan.

\subsubsection{Perumusan Masalah dan Solusi}

Wawancara dilakukan kepada pengurus dan anggota koperasi tentang kegiatan koperasi dan untuk mengetahui kendala apa saja yang dihadapi selama ini agar memiliki gambaran tentang materi yang akan disampaikan pada pelatihan penyusunan laporan keuangan. Berdasarkan diskusi dengan pengurus Koperasi Batik Cempaka Mulya permasalahan yang dihadapi koperasi adalah pengurus koperasi belum mampu menyusun laporan keuangan. Setelah diperoleh informasi mengenai permasalahan yang terjadi maka dilakukan perumusan masalah dengan tujuan mencari solusi yang dapat dilakukan

\subsubsection{Metode Penyelesaian Masalah}

Metode penyelesaian masalah dalam kegiatan pengabdian masyarakat ini adalah dengan melakukan pelatihan untuk membekali pengurus koperasi tentang penyusunan laporan keuangan koperasi Cempaka Mulya.

\subsubsection{Pelaksanaan Kegiatan}

Pelaksanaan kegiatan pengabdian berlangsung pada tanggal 1 Desemer 2016. Pelaksanaan kegiatan dilakukan pada pukul 08.00 WIB s,d selesai bertempat di Pendopo Kecamatan Bandung. Materi yang disampaikan terkait dengan tahapan dalam penyusunan laporan keuangan, media yang dibutuhkan dalam penyusunan laporan keuangan dan latihan kasus penyusunan laporan keuangan. Kegiatan pelatihan dimulai dengan memperkenalkan pentingnya laporan keuangan, jenis-jenis laporan keuangan yang wajib disusun oleh Koperasi kemudian dilanjutkan dengan pelatihan teknis menyusun laporan keuangan. Peserta pelatihan diperkenalkan dengan proses mengalasisis transaksi, mencatat transaksi ke jurnal umum, posting ke buku besar, menyusun neraca saldo, pembuatan jurnal penyesuaian dan penyusunan laporan keuangan. Pelaksanaan Pengabdian Kepada Masyarakat ini dilakukan dengan menggunakan metode ceramah, tutorial dan diskusi. Adapun sistematika pelaksanaan kegiatan pengabdian adalah sebagai berikut:

a. Meode Ceramah

Peserta diberikan motivasi agar memiliki pemahaman tetang koperasi dan penyusunan laporan keuangan koperasi. Peserta juga diberikan gambaran tentang perkembangan batik Tegalan dan pemasaran batik Tegalan serta pentingnya penyusunan laporan keuangan koperasi demi tercapainya administrasi keuangan yang memadai.

b. Metode Tutorial

Peserta pelatihan diberikan materi dan praktek penyusunan laporan keuangan. Peserta pelatihan dipandu untuk menyusun laporan keuangan koperasi.

c. Metode Diskusi

Peserta pelatihan diberikan kesempatan untuk mendiskusikan permasalahan yang berkaitan dengan penyusunan laporan keuangan koperasi dan permasalahan lainnya. 


\section{HASIL DAN PEMBAHASAN}

\subsection{Hasil Kegiatan}

Kegiatan pengabdian masyarakat ini di hadiri oleh kurang lebih 20 peserta yang terdiri dari anggota dan pengurus Kelompok Usaha Bersama di Kampung Batik BNI Tegal dan Koperasi Batik Tegalan Cempaka Mulya. Kegiatan ini disambut positif oleh masyarakat Kampung Batik maupun pihak Dinas terkait yaitu Dinas Perindustrian dan Perdagangan Kota Tegal (Disperindag) serta Kepala Bagian Pembiayaan dari BNI Kota Tegal.

Berdasarkan hasil pengamatan langsung, diskusi dan tanya jawab langsung selama kegiatan berlangsung, kegiatan pengabdian masyarakat ini memberikan hasil sebagai berikut:

a. Meningkatnya pengetahuan dan pemahaman tentang laporan keuangan koperasi, hal ini dapat dilihat dari hasil pengamatan, diskusi dan tanya jawab selama proses pelatihan.

b. Meningkatnya ketrampilan pengurus koperasi dalam menyusun laporan keuangan koperasi, hal ini dapat dilihat dari kemamampuan peserta pelatihan dalam menyusun laporan keuangan sesuai dengan latihan kasus yang diberikan oleh pemateri pelatihan.

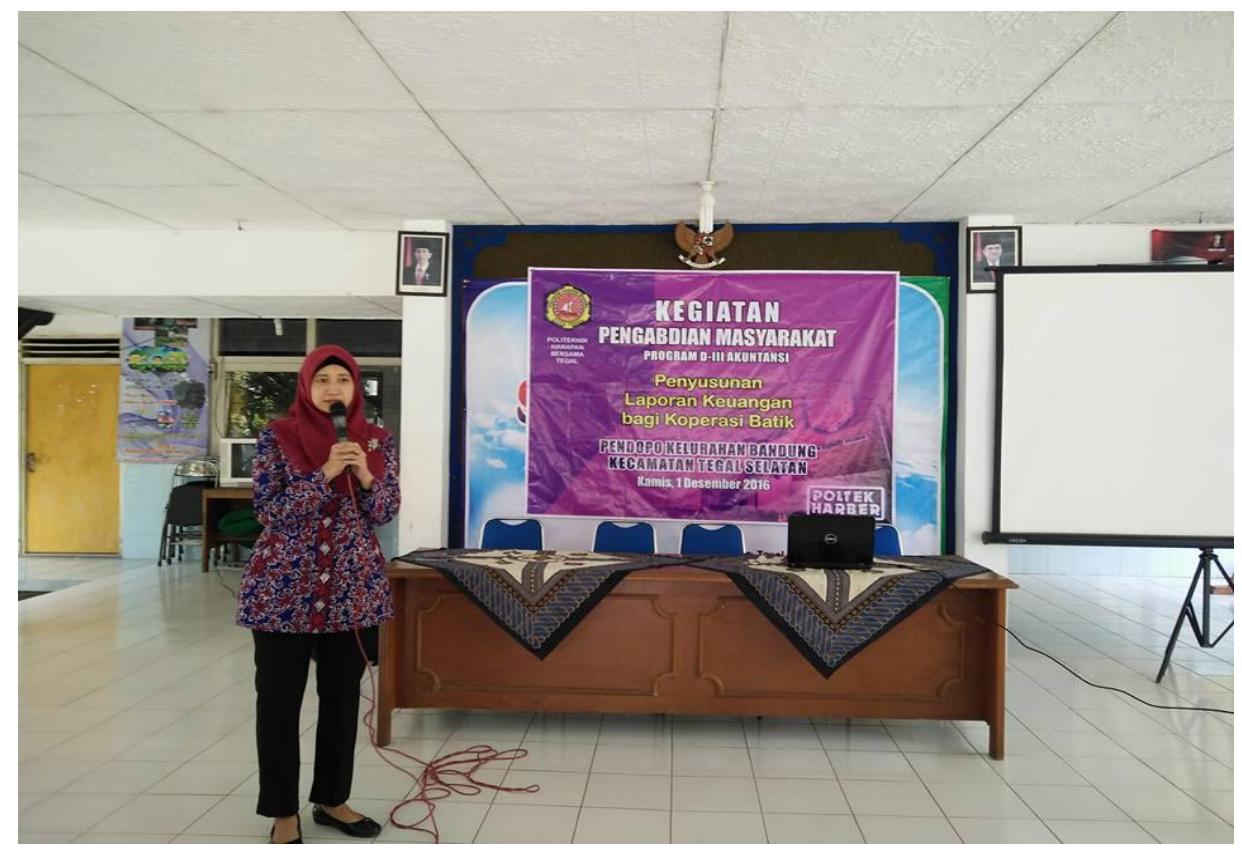

Gambar 1 Penyampaian Materi Pelatihan Penyusunan Laporan Keuangan oleh Anggota Tim Pengabdian Masyarakat 


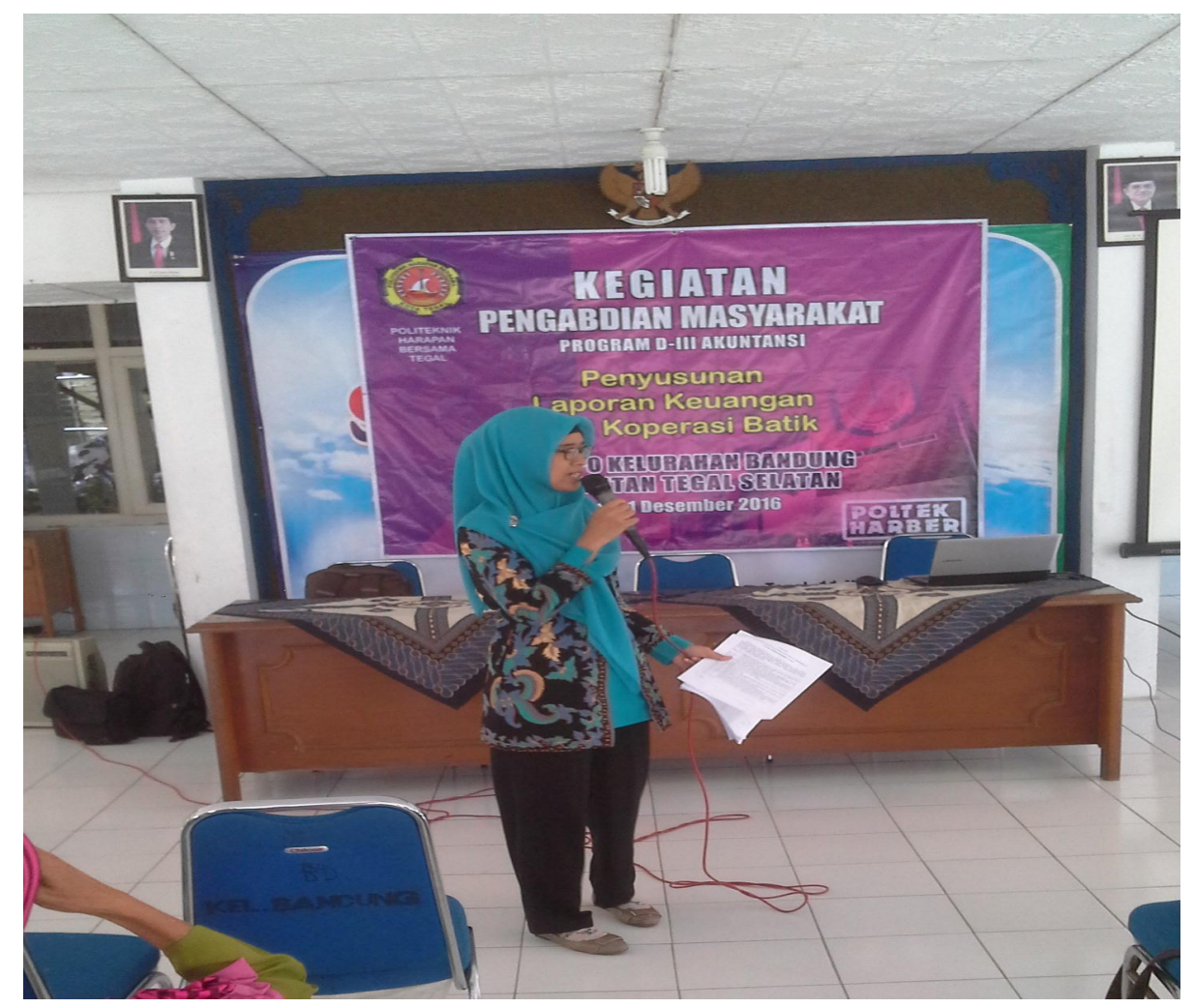

Gambar 2 Pemberian Materi Praktek Penyusunan Laporan Keuangan kepada Peserta Pelatihan

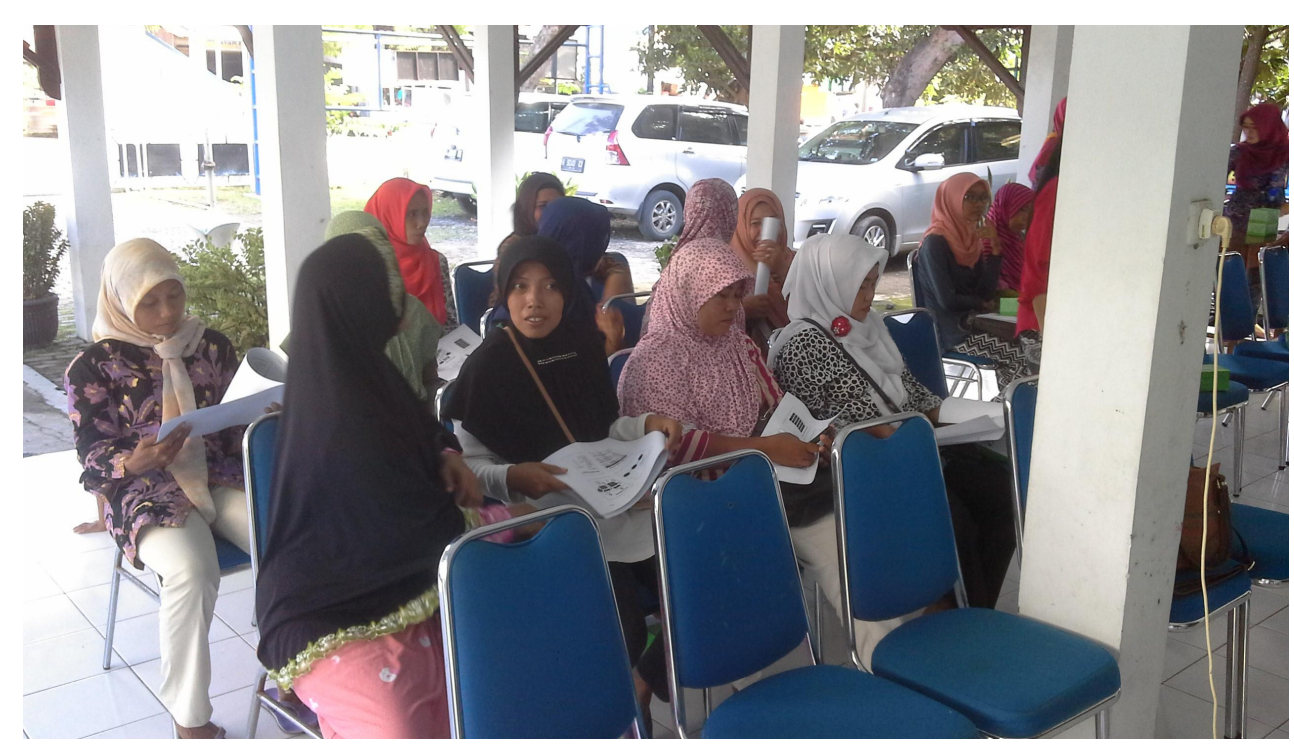

Gambar 3 Diskusi Penyusunan Laporan Keuangan pada Koperasi 


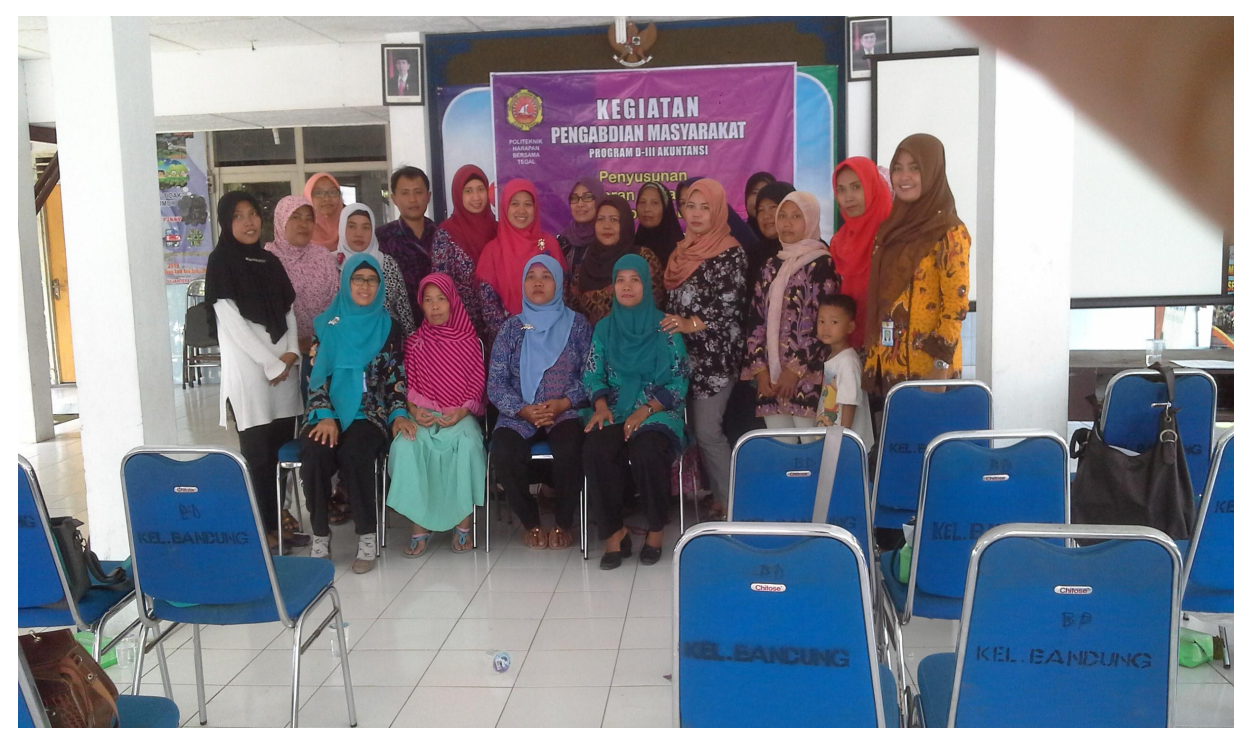

Gambar 3 Peserta dan Tim Pengabdian Masyarakat

Gambar 1, 23 dan 4 memperlihatkan kegiatan pelatihan yang diikuti oleh para pengurus koperasi dan anggota koperasi Batik Tegalan Cempaka Mulya. Pada kegiatan pengabdian masyarakat ini pemberian materi dilakukan oleh tim pelaksana PKM yang terdiri dari Dosen dan mahasiswa sebagai tim pembantu teknik pelaksanaan PKM.

\subsection{Pembahasan}

Koperasi adalah organisasi yang dijalankan dengan tujuan untuk kepentingan bersama. Koperasi Batik Tegalan Cempaka Mulya didirikan dengan tujuan untuk meningkatkan kesejahteraan anggota koperasi khususnya pengrajin Batik Tegalan. Kegiatan pelatihan penyusunan laporan keuangan pada pengurus koperasi Batik Tegalan telah mendapat dukungan dari Disperindag Kota Tegal dan Kepala Bagian Pembiayaan BNI Kota Tegal. Dengan adanya kegiatan pengabdian ini diharapkan dapat meningkatkan pemahaman dan kertampilan pengurus koperasi sehingga dapat menyajikan laporan keuangan koperasi yang transparan dan dapat dipertanggung jawabkan.

Kegiatan pelatihan dimulai dengan memperkenalkan macam-macam laporan keuangan koperasi dan jenis laporan keuangan yang wajib disusun oleh pengurus koperasi, kemudian dilajurkan dengan pelatihan teknis menyusun. Peserta pelatihan diperkenalkan dengan macam-macam laporan keuangan, proses penysunan laporan keuangan dan latihan penyusunan laporan keuangan berdasarkan contoh transaksi koperasi. Pelatihan yang dilaksanakan pada tanggal 1 Desember 2016 di Pendopo Kecamatan bandung mendapat respon sangat baik dari peserta pelatihan, tetapi karena keterbatasan waktu maka penyusunan laporan keuangan belum terselesaikan.

Satu minggu setelah pelaksanaan kegiatan pelatihan, tim pengabdian melakukan pendampingan pada pengurus koperasi batik untuk mengetahui apakah pengurus koperasi sudah mengimplementasikan materi hasil pelatihan dan kendala yang dihadapi oleh pengurus koperasi. Kendala yang dihadapi adalah pengurus koperasi kesulitan dalam menganalisis transaksi yang sudah terjadi sehingga pencatatan transaksi ke dalam jurnal terkendala, namun setelah dijelaskan kembali mereka sudah mampu mencatat transaksi sampai dengan tersusunnya laporan keuangan koperasi.

\section{KESIMPULAN}

Pelaksanaan pengabdian masyarakat ini telah berjalan sesuai denga jadwal yang telah direncanakan. Dari kegiatan pengabdian masyarakat yang telah dilaksanakan dapat disimpulkan bahwa: 
a. Tim pengabdian masyarakan Prodi Akuntansi telah berhasil melaksanakan Pelatihan Pengisian Penyusunan Laporan Keuangan pada Pengurus Koperasi Batik Cempaka Mulya.

b. Kegiatan pengabdian masyarakat yang dilakukan oleh Prodi Akuntansi dapat dikatakan berhasil dan mendapatkan tanggapan positif dari peserta, hal ini dapat dilihat dari tingkat kehadiran yang lebih dari 70 persen dari total peserta.

c. Pengetahuan, pemahaman dan ketrampilan peserta tentang penyusunan Laporan Keuangan mengalami peningkatan, hal ini dapat dilihat dari kemampuan peserta menyelesaikan soal latihan penyusunan laporan keuangan yang diberikan oleh pemateri.

d. Terjalin kemitraan antara Politeknik Harapan Bersama dengan Kelompok Usaha Bersama Kampung Batik, Disperindag Kota Tegal dan Kantor BNI Kota Tegal.

\section{SARAN}

Berikut ini beberapa masukan yang diberikan oleh peserta pelatihan:

a. Perlu ada pelatihan lanjutan mengenai keuangan atau materi pelatihan lainnya melihat manfaat dari hasil pelatihan telah dirasakan oleh masyarakat kampung batik,

b. Jumlah tatap muka atau waktu pelatikan disarankan ditambah agar materi yang disampaikan dapat diserap lebih maksimal lagi.

c. Perlu adanya pendampingan penyusunan laporan keuangan bagi pengurus Koperasi Batik Cempaka Mulya melihat transaksi yang kemungkinan akan bertambah dan lebih bervariasi sejalan dengan perkembangan Koperasi Batik.

\section{UCAPAN TERIMA KASIH}

Terima kasih kepada Pusat Penelitian dan Pengabdian Masyarakat (P3M) Politeknik Hrapan Bersama Tegal yang telah membiayai kegiatan PKM yang telah dilaksanakan ini pada tahun anggaran 2016.

\section{DAFTAR PUSTAKA}

[1] Sinarwati, Ni Kadek dkk. 2014. Pelatihan Penyusunan Laporan Keuangan Kepada Pengurus Koperasi Simpan Pinjam di Desa Antiga Kelod. Diundih pada (lppm.undiksha.ac.id/p2m/...Laporan_Akhir_197210202010122002\%20_2014.pdf)

[2] Kieso dan Weygandt. 2005. Akuntansi Intermediate. Edisi Ketujuh Jilid Satu. Jakarta: Bina Rupa Aksara. 